attributable to gastric causes, it is found that there was in 1933-35 some excess of gastric illnesses recorded among omnibus workers as compared with tramway workers at those age-groups to which the majority of the former belongs, though at these ages the total sickness experience, from all causes, of the omnibus workers was rather more favourable than that of the tramway workers.

\section{Japanese Trawlers in Indian Waters}

A LEADING article in Current Science of May directs attention to the rapidly increasing activity of Japanese trawlers in the Bay of Bengal. On more than one occasion the Government of India has been warned that unless adequate steps were taken to improve and develop Indian fisheries in Indian waters, some other country would sooner or later step in and exploit this area for its own benefit; but with the exceptions of the Government of Madras and, more recently, of Bombay, little or nothing has been done by either the Central or Provincial Governments. For some years past the average catches made by Japanese trawlers operating in the Pacific have been steadily decreasing, partly owing to increased competition but also in the main, no doubt, owing to over-fishing, and in consequence they are now seeking for more profitable areas in other waters. So long ago as 1908-9, the Golden Crown carried out a series of experimental trawls for the Government of Bengal, and these showed that there were a number of excellent trawling grounds in this area. The average catch obtained compared very favourably with those taken in European waters. The experiment was a failure from the financial side mainly because of difficulties in the distribution and marketing of the catches.

\section{Indian Coastal Fisheries and their Exploitation}

If the Japanese now working in the Bay of Bengal can overcome the marketing difficulties, there seems to be no doubt that they will very materially increase the supply of fresh fish in those ports to which they bring their catches, and in this respect will benefit the inhabitants; at the same time, it must be remembered that this is but one side of the fishing industry and that much material is obtained in the trawl that can be turned, by suitable treatment, to other uses, such as the preparation of dried and salted fish and the manufacture of fish-oil, fish-meal and even fish-manure. In the past, the bulk of the fish guano that is prepared in the Province of Madras is exported, through Ceylon, to other countries and particularly to Japan; the value of this export rose, under the fostering care of the Madras Fishery Department, from 188 tons, valued at Rs. 13,648 , in $1910-11$, to 32,000 tons, valued at Rs. 24,40,000 in 1922-23, and in 1927-28 it had risen even further to 100,000 tons. If the Japanese trawling in the Bay of Bengal proves to be a success, it is highly probable that in the very near future there will be a marked falling off in the sales to Japan of these Indian fishery products, to the great detriment of the Madras fishermen.
THE present Japanese invasion of Indian waters appears to have commenced in 1935 ; but its origin can probably be traced back to several years earlier. In 1929-30 the Japanese commenced a surreptitious exploitation of the Trochus -shell beds of the Andaman and Nicobar Islands by divers working from motorboats that were based on Singapore, and this in. creased to such an extent that the Government of India appointed a fishery research officer in 1931. Unfortunately, owing to lack of proper supervision, undersized shells were fished and, in the absence of any patrolling vessel, grounds that were supposed to be closed were poached, while considerable poaching on the authorized grounds was carried out by unlicensed vessels : in consequence, the shell-beds were rapidly decimated and will take many years to recover. Some of these motor-boats brought with them their fishing nets, and an experiment carried out off Port Blair showed that these nets could be used in these waters with very considerable success, one boat after an absence of two days returning with a catch of about $1 \frac{1}{2}$ tons of fish. The natural resources of the ocean are everywhere open to all nations outside the three-mile territorial limit, but unless adequate patrolling of these Indian coastal waters by fishery-protection vessels is carried out-and in view of the great length of coast-line involved this would seem to be impossible-Japanese trawlers will certainly exploit the inshore waters, should experience prove that they are profitable trawling-grounds. A comparison of the various species of fish brought to market by the local fishermen of Akyab in Burma and Puri in Orissa, on opposite sides of the Bay of Bengal, with those taken by the Golden Crown, reveals that a large percentage are identical. These local inshore fishing-grounds extend out from the coast for distances varying from about five miles up to as much as 10-15 miles; thus, even were the territorial limit of three miles strictly enforced for these trawlers, there can be little doubt that such trawling by Japanese vessels will affect adversely, and perhaps seriously, the Indian coastal fishing industry.

\section{National Institute of Sciences of India}

Prof. M. N. SAHA informs us that the Govern. ment of India has decided to make a grant-in-aid of Rs. 6,000 per annum to the National Institute of Sciences of India, Calcutta, with effect from 1937-38. The grant will be subject to the following conditions : (1) Provision should be made for a nominee of the Government of India on the Council of the Institute. (2) An annual report of the working of the Institute, together with a duly audited statement of accounts, should be furnished regularly to the Government of India. (3) The Institute should tender advice on any scientific problems which may be referred to it by the Government of India and discharge any other functions which may be assigned to it by the Government of India. No provision exists in the current year's budget of the Central Government for this grant. It is proposed, however, to include a sum of Rs. 12,000 in the budget estimates for 1938-39 